\title{
Synovial Cyst as an Uncommon Cause of Radiculopathy
}

\author{
Radikülopatinin Nadir Bir Nedeni Sinovial Kist
}

\author{
İdiris Altun, Kasım Zafer Yüksel
}

Kahramanmaraş Sütçü Imam Üniversitesi Tıp Fakültesi, Kahramanmaraş

\begin{abstract}
Synovial cysts develop as a result of herniation in the synovial membrane of the facet capsule. Synovial cysts, which are seen mostly in the 6th and 7th decades of life, are rarely seen in intraspinal, extradural lesions which lead to lower back pain and radiculopathy. Although they can be seen throughout the spinal region, the most common location is the lumbar L4-L5 disc space. It is very rare that location is in the cervical or thoracic regions and may be due to myelopathy in these regions. As those showing location in the lumbar area are close to the nerve root, radiculopathy may occur as a result of pressure on the nerve root. Diagnosis is made from a thick cystic structure seen adjacent to the facet joint on computed tomography and the determination of the capsule with contrast on magnetic resonance imaging. While conservative or surgical methods can be applied in treatment, the most commonly preferred method is surgery. In this paper, the case is presented of a 68-year old male patient with severe left leg pain, who was diagnosed with synovial cyst at the L4-L5 level.

In elderly patients with complaints of radiculopathy, synovial cysts must be considered in the differential diagnosis.
\end{abstract}

Pam Med J 2016;9(3):244-247

Key words: Radiculopathy, synovial cysts, elderly patients.

\section{Özet}

Sinoviyal kistler, faset kapsülünün sinoviyal zarında fıtıklaşma sonucu gelişirler. Yaşamın en çok 6. ve 7. dekadında görülen sinoviyal kistler, bel ağrısı ve radikülopatiye yol açan intraspinal ekstradural lezyonların nadir nedenleridir. Tüm spinal bölgede görülmelerine rağmen, en sık görüldükleri bölge L4-L5 disk aralığıdır. Servikal ve torasik bölgelerde görülmeleri nadirdir; görülürlerse bu bölgedeki miyelopatiye neden olabilirler. Lumbar alandaki görüldükleri bölge sinir köklerine yakın olduğundan, sinir kökü basısı sonucu radikülopati oluşabilir. Tanı, faset eklem komşuluğunda kalın kistik bir yapının bilgisayarlı tomografide görülmesi ve kontrast tutan kapsülün manyetik rezonans görüntülemesinde belirlenmesi ile konur. Konservatif veya cerrahi yöntemler tedavide uygulanabilmesi ile birlikte, en sık tercih edilen yöntem cerrahidir. Bu yazıda, L4-L5 seviyesinde sinoviyal kist tanılı şiddetli sol bacak ağrısı olan 68 yaşında erkek hasta sunulmuştur.

Radikülopati şikayetleri olan ileri yaş hastalarda, sinoviyal kist ayırıcı tanıda dikkate alınmalıdır.

Pam Tıp Derg 2016;9(3):244-247

Anahtar sözcükler: Radikülopati, sinovyal kist, ileri yaş hastalar.

\section{Introduction}

Synovial cyst that develops as a result of herniation in the synovia membrane of the facet capsule is an uncommon degenerative lesion seen particularly at an advanced age. The cyst content is serous or gelatinous and synovial cysts in the facet joint may develop due to arthrosis and rheumatoid arthritis and may accompany spondyolytic, degenerative pathologies in the spinal column. Cysts which develop due to changes in the intervertebral joints are known as juxtafacet cysts [1]. These develop both as synovial cysts from the synovia of small vertebral joints and as ganglion cysts from periarticular connective tissue [2]. Differentiation of synovial cysts and ganglion cysts is made by pathology examination of whether or not there is a synovial limiting membrane histologically $[2,3]$.

İdiris Altun

Yazışma Adresi: Kahramanmaraş Sütçü İmam Üniversitesi Tıp Fakültesi, Kahramanmaraş.

e-mail: idrisaltun46@hotmail.com 
Although they can be seen throughout the spinal region, the most common location is the lumbar L4-L5 disc space. It is very rare that location is in the cervical or thoracic regions and may be due to myelopathy in these regions. As those showing location in the lumbar area are close to the nerve root, radiculopathy may occur as a result of pressure on the nerve root. Diagnosis is made from a thick cystic structure seen adjacent to the facet joint on computed tomography (CT) and the determination of the capsule with contrast on magnetic resonance imaging (MRI) [4]. Although successful results have been reported from conservative treatment, surgical excision is necessary in cases with symptomatic radiculopathy who do not respond to conservative treatment [5]. In this paper, the case is presented of a patient diagnosed with intraspinal synovial cyst, with persistent complaints of leg pain, which did not respond to medical treatment.

\section{Case}

A 68-year old male patient who had experienced lower back and leg pain for many years presented at our clinic with the complaint of severe left leg pain which had been ongoing for 1 month. He stated that he had previously experienced lower back and leg pain but the recent pain in the left leg was different and more severe. The patient had no history of trauma and in the neurological examination, the Lasegue test was $45^{\circ}$ positive on the left, a deficit of $3+/ 5$ was determined in the left big toe muscle strength and left L4-L5 hypoesthesia. On lumbar MRI, a hyperintense synovial cyst was determined on T2-weighted sequences and at isointensity on T1-weighted sequences at the L4-L5 level, originating from the facet joint synovia on the left and causing pressure on the dura and L5 nerve root (Figure 1). Surgery is recommended for patients with severe leg pain and evident motor deficit. The current patient refused surgery, so an epidural injection was applied and medical treatment was started. During 3 weeks of follow-up with medical treatment, there was no change in the complaints of the patient or in the loss of motor strength. The patient then agreed to surgery and left L4 hemipartial laminectomy and flavectomy were applied. A hard, dirty yellow-coloured capsular cyst that orignated from the facet joint and was creating pressure on the neural root was totally excised and foramenectomy was applied. In the early postoperative period no complications developed and the complaint of leg pain recovered. The motor deficit recovered during the follow-up period and there were no additional complaints.

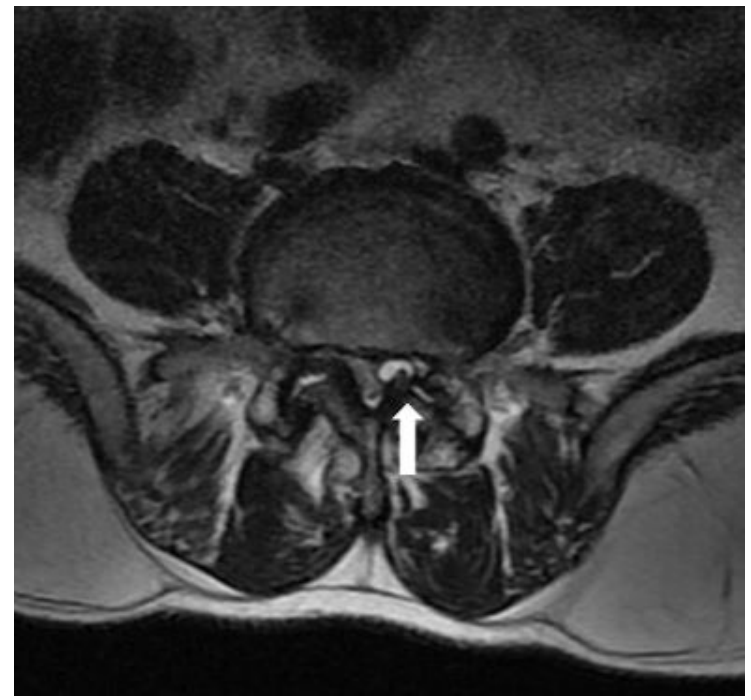

Figure 1. A hyperintense synovial cyst was determined at the L4-L5 level, originating from the facet joint synovia on the left and causing pressure on the dura and L5 nerve root on T2weighted axial MRI image.

\section{Discussion}

Synovial cysts are rarely seen intraspinal extradural lesions which lead to lower back pain and radiculopathy. Symptomatic radiculopathy which could develop associated with synovial cyst was first reported by Kao et al and ganglion and synovial cysts were named juxtafacet cysts [6]. Synovial cysts are periarticular cysts of the synovial membrane and are generally yellow and clear in colour, containing mucinous fluid or gas [6,7]. Ganglion cysts do not contain synovial covering and occur following cystic softening of the tendon sheath or joint capsule connective tissue and mixoid degeneration [7]. Although some authors consider synovial and ganglion cysts in the same context, they do not have the same pathology [7]. In current literature, juxtafacet cyst, rather than intraspinal facet cyst, is used to define synovial cysts [2].

Synovial cysts, which are seen mostly in the 6th and 7th decades of life, cause lower back pain and radiculopathy and occasionally neck pain [8]. It has been reported that $90 \%$ of synovial cysts are seen in the spinal column 
and less than $10 \%$ in the cervical and thoracic regions $[3,4,8]$. In the lumbar region, they are mostly seen at L4-L5 level [3]. Cysts with dorsal location are generally asymptomatic, whereas cysts with ventral location can cause radiculopathy from growth towards the neural foramen and spinal canal narrowing symptoms as a result of growth towards the spinal canal and can sometimes include both symptoms $[2,4,8]$. Clinically, the most common symptom is leg pain and neurodeficit is rarely seen, but myelopathic symptoms are observed more at the cervical and thoracic level $[2,5,7]$. In the current case, together with the complaint of leg pain there was an evident motor deficit.

Although the pathology of synovial cysts is not fully known, a significant cause is thought to be the mechanical loading on the spine $[4,8]$. Factors playing a role in the pathogenesis such as microtrauma, facet arthrosis and spondylolysthesis result in degeneration and membrane rupture and extracellular release of synovial fluid, proliferation of mesenchymal cells, mixoid degeneration in the collagen support tissue and an increase in hyaluronic acid production by fibroblasts $[7,8]$. In the current case as there had been a long period of pain in the lower back and both legs, it was thought that this could have been the result of a degenerative process.

Diagnosis of synovial cyst is best made with $\mathrm{MRI}$, and CT is only helpful in the visualization of the bone structures surrounding the cyst walls [9]. The MRI signal intensity of synovial cysts varies according to the properties of the cyst fluid. Actual synovial cysts containing clear serous fluid are seen as isointense on T1 and hyperintense on T2. Those with a viscous content have a more hyperintense character than CSF on both T1 and T2. If there are blood elements within the cyst, it will be seen with more evident hyperintensity. The appearance of the capsule wall will vary according to whether it is thick, thin or calcified. On contrast T1 images, contrast involvement is seen in the capsule wall [10]. In the differential diagnosis, there should be consideration of free disc fragments, neurofibroma, epidural or nerve root metastasis, dural subarachnoid nerve sheath dilation, arachnoid cysts, and perineural cysts (Tarlov cyst) $[2,7,9]$. In the current case, synovial cyst was considered as on MRI T1-weighted sequences, there was isointensity originating from the left facet joint synovium at L4-L5 level creating pressure on the dura and L5 nerve root and hyperintensity on the T2-weighted sequences.

While conservative or surgical methods can be applied in treatment, the most commonly preferred method is surgery $[2,4,5,7]$. Although clinical recovery is achieved in surgical treatment with simple decompression and cyst excision, in cases where there is degenerative lumbar spinal stenosis, when necessary, laminectomy, wide decompression and foramenotomy should be applied additional to cyst excision. Conservative treatment includes rest, analgesia, the use of a corset, steroid injection into the cyst, epidural steroid injection and aspiration of the cyst $[2,3,8]$. In a study examining the efficacy of conservative treatment, in 5 of 10 patients with unilateral radicular pain, intracystic corticosteroid injection and cyst aspiration was applied and in the other 5 , transforaminal epidural corticosteroid injection and cyst aspiration. In the follow-up period, pain completely recovered in only 1 patient and in the others the pain-free period was 3.4 weeks, so surgery was recommended for those 9 patients and it was concluded that surgical treatment was superior to conservative treatment [4]. In another study which compared surgical and conservative treatment results, in patients with no neurological deficit, the symptoms were seen to benefit from rest, the use of a corset, epidural steroid injection and steroid injection to the facet joint and in 7 of 8 patients treated with surgery, excellent and good results were obtained. As a result it was reported that conservative treatment could be applied to patients with no neurological deficit and in cases with radicular findings, surgical treatment should be applied [11]. Some authors have recommended surgical treatment in cases with persistent pain, progressive neurological deficit, symptomatic radiculopathy, myelopathy and those with caudal pressure [4,5]. In the current case, surgery was planned as there was an evident motor deficit. However, as the patient refused surgery, epidural steroid injection, analgesic therapy, corset and rest were applied for 1 month but the complaints of the patient did not recover. In the surgery that was then applied, decompression and foramenotomy were made together with cyst excision and the patient complaints and the neurological table recovered. 
In conclusion, in elderly patients with complaints of radiculopathy, synovial cysts must be considered in the differential diagnosis. In synovial cysts cases with a neurological deficit and lor who do not respond to conservative treatment, surgery can be considered an effective treatment method.

Conflict of interest: The authors declared no conflict of interest.

\section{References}

1. Oertel MF, Ryang YM, Gilsbcah JM, Rohde V. Lumbar foraminal and far lateral juxtafacet cyst of intraspinal origin. Surgical Neurology 2006;66:197-199.

2. Erbaş YC, Göçmen S, Yılmaz E, Erdoğan E. lumbar radiculopathy due to synovi al cyst: case report. Ortadogu Medıcal Journal 2013;5:53-54.

3. Kahiloğulları $\mathrm{G}$, Tuna $\mathrm{H}, \mathrm{Attar} \mathrm{A}$. Management of spinal synovial cysts. Turkish Neurosurgery 2008;18:211214.

4. Shah RV, Lutz GE. Lumbar intraspinal synovial cysts: conservative management and review of the world's literature. Spine J 2003;3:479-488.

5. Stoodley MA, Jones NR, Scott G. Cervical and thoracic juxtafacet cysts causing neurologic deficits. Spine 2000;25:970-973.

6. Kao CC, Uihlein A, Bickel WH, Soule EH. Lumbar intraspinal extradural ganglion cyst. J Neurosurg 1968;29:168-172.

7. Akgül O, Gezen AF. Radikülopatiye yol açan lomber bölge ganglion kisti. Sinir Sistemi Cerrahisi Derg 2014:4:9-13.

8. Trummer M, Flaschka G, Tillich M, Homann C, Unger F, Eustacchio S. Diagnosis and surgical management of intraspinal synovial cysts: report of 19 cases. J Neurol Neurosurg Psychiatry 2001;70:74-77.

9. Yamamoto A, Nishiura I, Handa H, Kondo A. Ganglion cyst in the ligamentum flavum of the cervical spine causing myelopathy: report of two cases. Surg Neurol 2001;56:390-395.

10. Boviatsis EJ, Staurinou LC, Kouyialis AT, Gavra MM, Stavrinou PC, Themistokleous M, et al. Spinal synovial cysts: pathogenesis, diagnosis and surgical treatment in a series of seven cases and literature review. Eur Spine J 2008;17:831-837.

11. Hsu K Y, Zucherman JF, Shea WJ, Jeffrey RA. Lumbar intraspinal synovial and ganglion cysts (facet cysts). Ten-year experience in evaluation and treatment. Spine 1995;20:80-89. 